\title{
Evaluation of the Relationship Between Hashimoto's Thyroiditis and the Course of COVID-19 Infection
}

\author{
Hashimoto Tiroiditi ile COVID-19 Enfeksiyonu Gidişatı Arasındaki \\ İlişkinin İncelenmesi \\ Hasret Cengiz ${ }^{1}$, Taner Demirci ${ }^{1}$, Ceyhun Varım ${ }^{2}$ \\ ${ }^{1}$ Department of Endocrinology and Metabolism, Sakarya University Medicine Faculty, Sakarya,Turkey. \\ ${ }^{2}$ Department of Internal Medicine, Sakarya University Medicine Faculty,Sakarya,Turkey. \\ Yazışma Adresi / Correspondence: \\ Hasret Cengiz \\ Adnan Menderes Caddesi, Sağlık Sokak, No: 195-54000, Adapazarı/Sakarya \\ T: +902642552106 E-mail : drhasretc@gmail.com \\ Geliş Tarihi / Received : 30.07.2021 Kabul Tarihi / Accepte: 04.12.2021 \\ Orcid : \\ Taner Demirci https://orcid.org/0000-0002-9579-4530 \\ Ceyhun Varım https://orcid.org/0000-0002-8369-0857 \\ Hasret Cengiz https://orcid.org/0000-0002-5216-3368 \\ ( Sakarya Tip Dergisi / Sakarya Med J 2021, 11(4):803-809) DOI: 10.31832/smj.976529
}

\begin{abstract}
Objective Coronavirus infection (COVID-19) has caused a worldwide pandemic and affected many systems. Hashimoto's Thyroiditis is one of the most common diseases in the community and is the prototype of autoimmune thyroid diseases. It is unknown how thyroid autoimmunity and thyroid dysfunction will affect the course of COVID-19. The aim of this study is to show the course of this infection in patients with Hashimoto's Thyroiditis.

Materials A descriptive study was conducted in which adult patients with Hashimoto's Thyroiditis who received COVID-19 infection from April to October 2020 in our center were and Methods recruited retrospectivelly. Those with severe comorbid conditions that may affect the course of the disease,and using immunomodulatory and immunosuppressive drugs, and pregnant women were not included in the study.

Results A total of 232 patients included. Median (IQR=interquartile) age value was 43 (34-54), and the male/female ratio was 21/211 (9.1\%/90.9\%). In our study, mortality due to COVID-19 in our patients was found to be consistent with the normal population in their age group $(1,7 \%, \mathrm{n}: 4)$, and 7 patients were treated in the intensive care unit. A significant negative correlation was found between Anti-Tyroglobuline Antibody (Anti-Tg) and White Blood Cell (WBC) $(r=-0.189, p=0.041)$, Neutrophil $(r=-0.191$, $\mathrm{p}=0.040)$, Neutrophil to Lymphocyte Ratio (NLR) $(\mathrm{r}=-0.244, \mathrm{p}=0.008)$, Ferritin $(\mathrm{r}=-0.259, \mathrm{p}=0.042)$.

Conclusion The rate of patients with supressed Thyroid Stimulating Hormone (TSH) in intensive care unit was slightly higher, but since the number of events was low, this finding could not gain significance. Most patients with Hashimoto's Thyroiditis have had a mild infection. Thyroid autoimmunity does not appear to affect the COVID-19 infection's course.

Keywords COVID-19; Hashimoto’s Thyroiditis; Autoimmune Thyroid Disease

Öz

Amaç Coronavirus enfeksiyonu (COVID-19) dünya çapında bir pandemiye yol açmış ve pek çok sistemi etkilemiștir. Hashimoto Tiroiditi toplumda sik görülen hastalklardan birisi ve otoimmun tiroid hastalklarının prototipidir. Tiroid otoimmunitesi ve tiroid fonksiyon bozukluğunun COVID-19 seyrini nastl etkileyeceği bilinmemektedir.Bu çalş̧madaki amaç bu enfeksiyonun Hashimoto Tiroiditi hastalarindaki seyrini göstermektir.

Gereç ve Merkezimizde Nisan-Ekim 2020 tarihleri arasında gelen COVID-19 enfeksiyonu geçirmiş erişkin Hashimoto Tiroiditi hastalarının alındı̆̆ı tanımlayııı bir çallşma yapıldı. Hastalı̆̆ın gidişa-

Yöntemle tın etkileyebilecek ă̆ır komorbid durumları olanlar ve immunmodülatuar ve immunsupresif ilaç kullanan kişiler ve gebeler çallşmaya alınmadı.

Bulgular Total 232 hastada Median (IQR=interquartile) yaș değeri 43 (34-54),Erkek/kadın oranı 21/211 (9.1\%/90.9\%) idi. Hastalarımızda COVID-19 nedeni ile mortalite kendi yas gruplarındaki normal toplum ile uyumlu (\%1,7,n:4) bulunmuş olup 7 hasta yoğun bakımda tedavi görmüștür. Anti-Tiroglobulin Antikoru (Anti-Tg) ile Beyaz Kan Hücreleri $(r=-0.189$, $p=0.041)$, Nötrofil $(r=-0.191, p=0.040)$, Nötrofil-Lenfosit Orant $(r=-0.244, p=0.008)$ ve Ferritin $(r=-0.259, p=0.042)$ ile arasinda anlamlı düzeyde negatif korelasyon ilișkisi saptanmıștur.

Sonuç Yoğun bakıma alınan hastalarda Tiroid Stimulan Hormonu (TSH) baskll olanların oranı biraz yüksek çımış fakat vaka sayısı düşük olduğundan anlamllılk kazanmamıştrt.Hashimoto Tiroiditi hastalarının çoğu enfeksiyonu hafif geçirmiștir. Tiroid otoimmunitesi COVID-19 enfeksiyonu seyrini etkilemiyor gibi görünmektedir.




\section{INTRODUCTION}

Coronavirus injection (COVID-19) first appeared in the Wuhan Province of China in late 2019 and leading to a major worldwide pandemic. The cause of this pandemic is Severe Acute Respiratory Syndrome Coronavirus 2 (SARSCoV-2) an enveloped non-segmented single-stranded RNA virüs. ${ }^{1,2}$ The disease is mostly asymptomatic or survived with mild flu like symptoms, but sometimes causes mortality with acute respiratory distress syndrome, sepsis and multiorgan dysfunction due to cytokine storm. While the morbidity and mortality of the disease is lower in young adults and middle-aged people, it is much higher in the patients who are elderly and with comorbid diseases such as hypertension, diabetes, and obesity. ${ }^{1,2}$

The virus attaches to the cells by the interaction of the spike protein with the Angiotensin Converting Enzyme (ACE-2) receptor on the cell membrane and is invades into the cell with the help of Transmembrane Serine Protease 2. In humans, the virus mostly affects the respiratory, cardiovascular, gastrointestinal and neurological systems and presents with a wide variety of findings. ACE-2 receptor is also found in many tissues in the endocrine system, including the pituitary and thyroid. ${ }^{3}$ In the course of COVID-19, many thyroid disorders such as low TSH due to disruption of the pituitary thyroid axis, isolated low T3 due to euthyroid sick syndrome and atypical subacute thyroiditis have been shown in many studies. It is thought that these may be due to direct cytopathic effect of the virus but more likely through the immunogenic pathways. ${ }^{4}$

Chronic Lymphocytic Thyroiditis, also known as Hashimoto's Thyroiditis, is the most common cause of hypothyroidism in iodine-sufficient populations. ${ }^{5}$ The majority of these patients are stable with L-thyroxine treatment. Although their susceptibility to COVID-19 infection and whether they are in the more vulnerable group in terms of severe infection and mortality are still controversial.

While many endocrinological and metabolic diseases such as diabetes mellitus and obesity have been defined as risk factors for COVID-19 infection, it is stated that autoimmune thyroid patients do not carry a high risk for COVID-19 infection. There are no additional warnings for COVID-19 infection for autoimmune thyroid patients in the current guides. ${ }^{4,6,7}$ However, there are not enough studies to clarify this issue yet. Therefore, we tried to detect the correlation of autoimmunity markers with acute inflammation markers and determine whether there is an additional risk in terms of disease severity and mortality in our own group of Hashimoto's Thyroiditis patients who had COVID-19 infection.

\section{MATERIALS and METHODS}

A descriptive study was conducted in which adult patients with Hashimoto's Thyroiditis who applied to Sakarya University Training and Research Hospital Faculty of Medicine between April and October 2020 were included in the study. Among these patients, those with positive COVID-19 test were retrospectively screened. Patients with active cancer and rheumatological diseases and autoimmune diseases such as celiac, diabetic and hypertensive patients and also patients with serious comorbidities that may affect the course of the disease such as heart failure, chronic obstructive pulmonary disease, cirrhosis or chronic kidney failure, those using immunomodulatory and immunosuppressive drugs and pregnant women were excluded. Diagnosis of Hashimoto's Thyroiditis was made by determining thyroid autoantibody (Anti Thyroid Peroxidase (Anti-TPO) and Anti-Tg) positivity and detecting diffuse heterogeneity compatible with chronic thyroiditis on ultrasound. Thyroid Ultrasounds were performed by the same author with B Mode High Resolution USG device Logic 9, General Electric USA ${ }^{\star}$. Serum Thyroxine (fT4), TSH, Anti-TPO and Anti TG levels were measured by the chemiluminescent microparticle immunological method in the Abbott Architect I 2000 SR $^{\circledast}$ device with appropriate commercial reagents and kits. The cut off value for Anti-TPO positivity was $35 \mathrm{IU} / \mathrm{ml}$ and $40 \mathrm{IU} / \mathrm{ml}$ for Anti-Tg,the normal range for the TSH level was taken as 0,5-5 
$\mathrm{mIU} / \mathrm{L}$ and $\mathrm{ft} 4$ was taken 9.1- 19.9 pmol / $\mathrm{L}$ in accordance with laboratory calibration guidelines

Nasal and pharyngeal swabs were obtained from all patients. Isolated patient samples that were obtained with viral nucleic acid test (VNAT) viral transport, brought to the molecular virology laboratory and examined using Biospedy (Bioeksen Ar Ge Technology Ltd. ,Sti.Sarıyer,Istanbul, Turkey) rRT-PCR kits provided by the Ministry of Health of Turkey. The patients whose RT-PCR results were positive were regarded as COVID-19 (+).

Hemogram, C-Reactive Protein (CRP), Ferritin, Fibrinogen, D-Dimer and Troponin values were also measured along with the thyroid function tests and Anti-TPO, Anti-Tg antibodies of the patients. Blood samples were taken on the day when the patient presented to the emergency department or outpatient clinic symptomatically and the COVID-19 test was positive. For biochemical acute phase parameters the samples were placed into a dry tube and investigated using a Beckman Coulter AU680 ${ }^{\circ}$ with Beckman Coulter kits. Blood was placed into the EDTA tube for a hemogram examination via a WIC-LYSE for CELL DYN 3700 Kits on the Abbott Cell-Dyn $3700^{\circledR}$ Device. The CRP parameter was studied with SIEMENS BN II ${ }^{\circledR}$ with Cardio $\mathrm{P}$ hase hsCRP $\mathrm{WN}^{\oplus}$ kits. Neutrophil Lymphocyte ratio was calculated by dividing absolute neutrophil count by absolute lymphocyte count. Demographic and biochemical data were scanned retrospectively from the hospital's online system. The study complies with the Declaration of Helsinki Principles.Ethics approval was obtained from the local ethics committee of our university for the study. (Ethics Committee No:E-71522473-050.01.04-45395-389)

\section{Statistical analysis}

Data analysis was performed by using SPSS-22 for Windows (Statistical Package for Social Science, SPSS Inc. Chicago IL, USA $\left.{ }^{\oplus} \mathrm{Z}\right)$. The variables were investigated using visual (histograms, probability plot) and analytical method (Kolmogorov-Simirnov) to determine whether or not they are normally distributed. We performed analyses to describe and summarize the distributions of variables. The continuous variables were expressed as mean and standard deviation or as median and interquartile range, depending on the normality of their distribution. The differences between qualitative/categorical variables such as gender distribution between groups were compared with the chisquare test since the values observed in the cells provided assumptions. While investigating the associations between non-normally distributed variables, the correlation coefficients and their significance were calculated using Spearman's test. The statistically significant two tailed p-value was considered as $<0.05$.

\section{RESULTS}

Two hundred and thirty two patients with Hashimoto's Thyroiditis diagnosed with autoantibody positivity and/ or ultrasonography findings were included in the study. The median (IQR=interquartile) age value was 43 (34-54). The male/female ratio was $21 / 211$ (9.1\%/90.9\%), and 177 $(76.3 \%)$ of the cases were receiving thyroid hormone replacement therapy. The median (IQR) L-thyroxine replacement dose in the treated group was 100 (50-100) mcg/day. According to the TSH analysis performed at the time of diagnosis of COVID-19 infection, 20 (8.6\%) of the patients were hyperthyroid $(\mathrm{TSH}<0.5 \mathrm{mIU} / \mathrm{L}), 172$ (74.1\%) were euthyroid (TSH 0.5-5.0 mIU/L ) and 40 (17.2) \%) were in the hypothyroid (TSH >5.0 mIU/L). Clinical and laboratory features are summarized in Table-1.

Seven $(3.0 \%)$ of the 232 patients followed were severe enough to require intensive care. The median (IQR) age and TSH value of these patients were 39 (35-56) and 2.20 (0.42-3.63), respectively. In addition, $4(1.7 \%)$ patients died and the median (IQR) age and TSH value of these patients were 46 (31.5-63.5) and 1.99 (0.65-3.38). When the patients grouped according to TSH level, the numbers of those who needed intensive care support in the hyperthyroid, euthyroid and hypothyroid groups were 2 (10\%), 4 $(2.3 \%)$ and $1(2.5 \%)$, respectively $(\mathrm{p}=0.161)$ and the num- 
ber of deaths was $1(5.0 \%)$ in the hyperthyroid group and 3 $(1.7 \%)$ in the euthyroid group, respectively, while no death was observed in the hypothyroid group ( $\mathrm{p}=0.374)$.

\begin{tabular}{|c|c|}
\hline Variables & Results \\
\hline Age, years & $43(34-54)$ \\
\hline TSH, mIU/L & $2.13(1.22-3.72)$ \\
\hline$<0.5, \mathrm{n}(\%)$ & $20(8.6)$ \\
\hline 0.5-5.0, n (\%) & $172(74.1)$ \\
\hline$>5.0, \mathrm{n}(\%)$ & $40(17.2)$ \\
\hline Anti TPO, IU/mL & $8.0(0.5-223.3)$ \\
\hline Anti Tg, IU/mL & $6.3(1.8-34.3)$ \\
\hline \multicolumn{2}{|l|}{ Gender, n (\%) } \\
\hline Female & $211(90.9)$ \\
\hline Male & $21(9.1)$ \\
\hline White blood cell count, $103 / \mathrm{mm} 3$ & $7.67 \pm 2.60$ \\
\hline Absolute neutrophil count, $103 / \mathrm{mm} 3$ & $4.65 \pm 2.40$ \\
\hline Absolute lymphocyte count, $103 / \mathrm{mm} 3$ & $2.22 \pm 0.81$ \\
\hline NLR & $1.78(1.38-2.47)$ \\
\hline C-reactive protein $(\mathrm{CRP}), \mathrm{mg} / \mathrm{L}$ & $5.3(3.1-11.0)$ \\
\hline Fibrinogen, $\mathrm{mg} / \mathrm{dL}$ & $292 \pm 109$ \\
\hline D-dimer, ng/mL & $178(110-311)$ \\
\hline Troponin, ng/L & $1.4(0.7-5.6)$ \\
\hline Ferritin, ng/mL & $107.8 \pm 106.6$ \\
\hline \multicolumn{2}{|c|}{$\begin{array}{l}\text { *The results for continuous variables were expressed as mean and } \\
\text { standard deviation or as median and interquartile range, depend- } \\
\text { ing on the normality of their distribution. } \\
\text { Abbreviations: NLR, neutrophil to lymphocyte ratio. }\end{array}$} \\
\hline
\end{tabular}

The possible relationship between thyroid autoimmune antibody levels and some inflammation markers used in the evaluation and follow-up of the clinical severity of the disease during COVID-19 infection was evaluated by correlation analysis. While no significant correlation was found between Anti-TPO and any inflammation marker but there were a significant negative correlation relationship between Anti-Tg and WBC ( $\mathrm{r}=-0.189, \mathrm{p}=0.041)$, Neu $(\mathrm{r}=-0.191, \mathrm{p}=0.040), \mathrm{NLR}(\mathrm{r}=-0.244, \mathrm{p}=0.008)$ ve Ferritin $(\mathrm{r}=-0.259, \mathrm{p}=0.042)$ (Table 2).
Table 2. Correlation analysis (Spearman's correlations) between some serum inflammatory markers and thyroid autoimmune antibodies

\begin{tabular}{|l|c|c|c|c|}
\hline & \multicolumn{2}{|c|}{ Anti TPO } & \multicolumn{2}{c|}{ Anti Tg } \\
\hline & r value & p value & r value & p value \\
\hline Anti TPO & 1.000 & - & 0.582 & $<\mathbf{0 . 0 0 1}$ \\
\hline Anti Tg & $\mathbf{0 . 5 8 2}$ & $<\mathbf{0 . 0 0 1}$ & 1.000 & - \\
\hline WBC & -0.149 & 0.097 & $\mathbf{- 0 . 1 8 9}$ & $\mathbf{0 . 0 4 1}$ \\
\hline Neu & -0.123 & 0.176 & $\mathbf{- 0 . 1 9 1}$ & $\mathbf{0 . 0 4 0}$ \\
\hline Lym & 0.000 & 0.997 & 0.108 & 0.245 \\
\hline NLR & -0.110 & 0.229 & $\mathbf{- 0 . 2 4 4}$ & $\mathbf{0 . 0 0 8}$ \\
\hline D-dimer & 0.054 & 0.623 & -0.100 & 0.384 \\
\hline Fibrinogen & 0.045 & 0.768 & -0.109 & 0.502 \\
\hline Ferritin & -0.143 & 0.240 & $-\mathbf{0 . 2 5 9}$ & $\mathbf{0 . 0 4 2}$ \\
\hline Troponin & 0.095 & 0.535 & -0.061 & 0.710 \\
\hline $\begin{array}{l}\text { C-reactive protein } \\
\text { (CRP) }\end{array}$ & 0.183 & 0.102 & 0.087 & 0.457 \\
\hline Abbreiati & & & &
\end{tabular}

Abbreviations: TPO, thyroperoxidase; Tg, thyroglobulin; WBC, white blood cell count; Neu, neutrophil; Lym, lymphocyte; NLR, neutrophil to lymphocyte ratio

\section{DISCUSSION}

The COVID-19 Pandemic is a very serious epidemic that affects our country and the whole world. The disease caused very serious health expenditures, left many sequelae and became a cause of serious morbidity and mortality. It has significantly affected social life and economic balances worldwide 7,8

In our study we tried to observe how the COVID-19 infection progressed in our autoimmune thyroiditis patient group. The overall mortality of the disease was reported as 3.4\% according to the literature. ${ }^{7,8}$ In surveillance studies conducted in China and the United States, mortality in 4-5 decades has been reported as $2.3-2.7 \% .{ }^{9,10}$ In a study conducted in Turkey, 4 deaths were reported in 222 patients. The median age was 50 and $22 \%$ of whom were evaluated as severe disease. ${ }^{11}$ Our mortality rate was $1.7 \%$ (n:4) slightly below these rates, which may be due to the exclusion of patients with severe comorbidities and gender distribution mismatch. Nevertheless it was quite compatible with the age matched general community. Although 
it is thought that Hashimoto's thyroiditis does not affect mortality in the course of COVID-19, the number of our cases was unfortunately insufficient to provide statistical significance.

Most of our patients were stable patients under L-thyroxine replacement. In our study, there was no increase in hospitalization and death to the intensive care unit. Subclinical and overt hyperthyroidism seen in the minority of our whole patient group. Although there were small number of cases in this TSH supressed group the rate of it was was slightly higher in treated in intensive care unit. In support of this, in a study conducted in Italy, 20.2\% thyrotoxicosis was found among severe COVID-19 patients. $^{12}$ In the study by Muller et al. a correlation was found between TSH suppression and the frequency of hospitalization and intensive care unit stay in COVID-19 patients who did not have a known thyroid disease and did not receive $L$ thyroxine replacement. ${ }^{13}$

It is not known how thyroid autoimmunity affects the course of infection. It is said that the underlying uncontrolled thyroid disease may aggravate the COVID-19 infection. ${ }^{2,14}$ In the study by Zhang et al. COVID-19 patients with thyroid dysfunction were compared with those without; Acute phase reactants such as CRP, procalcitonin and $\mathrm{LDH}$ were found to be higher, lymphocytes were found to be significantly lower and hospitalization rate and hospital stay longer than 28 days were found to be significantly increased in patients with thyroid dysfunction. ${ }^{14}$ In another study, a significant correlation was found between documented thyroid disease in 433 patients and the poor course of COVID-19. ${ }^{15}$ According to a meta-analysis including eight studies, having a thyroid disease was found to be significantly associated with severe COVID-19 infection. ${ }^{16}$ Contrary to these studies, no significant difference was found in the duration of COVID-19 infection and hospitalizations in 10 chronic autoimmune patient groups, including 4 patients with Hashimoto's Thyroiditis under treatment. ${ }^{17}$ In another study conducted in Iran, it was shown that autoimmunity did not affect the mortali- ty of COVID-19 in Hashimoto Thyroiditis patients under L-Thyroxine treatment. ${ }^{18}$ In the USA, 251 hypothyroid patients were examined and it was shown that hypothyroidism did not affect hospitalization mechanical ventilation and death rates.19 Also in a population-based study conducted in Denmark, hypothyroid and hyperthyroid patients were examined in terms of catching COVID-19 infection and prognosis, and no difference was found compared to the normal population. ${ }^{20}$ In our study, we obtained results consistent with these latest studies in autoimmune thyroid patients, most of whom were under L-thyroxine treatment and were euthyroid.

We found a negative correlation between the acute phase parameters used in the disease and the Anti-Tg antibody. So that the high Anti-Tg titer seems to protective against the imflammatory burden.In the only study by Güven et al from Turkey that giving correlation analyses between thyroid autoantibodies and disease severity; Anti-TPO level was found to be significantly higher in intensive care patients compared to service patients, that is,Anti-TPO was found to be positive correlated with severe COVID-19 disease but Anti-Tg was not. ${ }^{21}$ In this study,a correlation was found between thyroid autoimmunity, high inflammatory load and worsening of COVID-19, contrary to our study.

There are some important limitations of our study. Our study is a single-center retrospective descriptive study with limited number of cases. A separate control group of COVID-19 positive patients without autoimmune thyroid disease was not used. The follow-up period of the patients is short and the limited number of cases and events makes it difficult to clearly distinguish between the groups in terms of mortality and morbidity. In addition, the acute effects of immunosuppressive drugs used to prevent the cytokine storm seen in the course of COVID-19 on the course of autoimmune thyroid disease are unknown. However, our study includes a high number of Hashimoto's Thyroiditis patients compared to other studies in the literature, and it is thought that it will contribute to the 
literature in this respect.

Thyroid hormones affect many physiological pathways and have important effects on immune system activities. It is known that T4 hormone regulates the level of ACE-2 receptors on tissues through integrin proteins. ${ }^{2,22}$ In addition, the already existing immune system activation in autoimmune thyroid disease seems to theoretically affect the course of the disease. On the contrary, the immune activation caused by COVID-19 can increase autoimmune conditions. ${ }^{1,2,4,22}$ A full understanding of this interaction requires further prospective large scale studies. Our study showed that the clinical course of COVID-19 infection in patients with Hashimoto's Thyroiditis was relatively benign and gave a perspective in this respect.

\section{Ethics Committee Approval}

Sakarya University Ethics Commitee. (14.07.2021) (Ref.

No.: 71522473/050.01.04-45395-389) 
Sakarya Med J 2021;11(4):803-809

CENGIZ et al., : COVID-19\&Hashimoto Thyroiditis

Kaynaklar

1. Chen W, Tian Y, Li Z, Zhu J, Wei T, Lei J. Potential Interaction Between SARS-CoV-2 and Thyroid: A Review. Endocrinology 2021;162(3):bqab004.

2. Duntas LH, Jonklaas J. COVID-19 and Thyroid Diseases: A Bidirectional Impact. J Endocr Soc 2021;5(8):bvab076.

3. Li MY, Li L, Zhang Y, Wang XS. Expression of the SARS-CoV-2 cell receptor gene ACE2 in a wide variety of human tissues. Infect Dis Poverty 2020;9(1):45.

4. Șandru F, Carsote M, Petca RC, Gheorghisan-Galateanu AA, Petca A, Valea A, et al. COVID-19-related thyroid conditions (Review). Exp Ther Med 2021;22(1):756.

5. Ragusa F, Fallahi P, Elia G, Gonnella D, Paparo SR, Giusti C,et al. Hashimotos' Thyroiditis: Epidemiology Pathogenesis Clinic and Therapy. Best Pract Res Clin Endocrinol Metab 2019;33(6):101367.

6. Dworakowska D, Grossman AB. Thyroid disease in the time of COVID-19.Endocrine 2020;68(3):471-474

7. Speer G, Somogyi P. Thyroid complications of SARS and coronavirus disease 2019 (COVID-19).Endocr J 2021;68(2):129-136.

8. Kakodkar P, Kaka N, Baig MN. A comprehensive literature review on the clinical presentation, and management of the pandemic coronavirus disease 2019 (COVID-19). Cureus 2020;12(4):e7560

9. Stokes EK, Zambrano LD, Anderson KN, Marder EP,Raz KM, Felix SEB.et al. Coronavirus Disease 2019 Case Surveillance - United States, January 22-May 30, 2020. MMWR Morb Mortal Wkly Rep 2020;69(24):759-765.

10. Cunningham JW, Vaduganathan M, Claggett BL, Jering KS, Bhatt AS, Rosenthal N Clinical Outcomes in Young US Adults Hospitalized With COVID-19. JAMA Intern Med 2020;181(3):379-381.

11. Güner R, Hasanoğlu İ, Kayaaslan B, Aypak A, Kaya Kalem A, Eser F et al. COVID-19 experience of the major pandemic response center in the capital: results of the pandemic's first month in Turkey.Turk J Med Sci 2020;50(8):1801-1809.

12. Coperchini F, Chiovato L,Croce L,Magri F,Rotondi M. The cytokine storm in Covid-19: an overview of the involvement ofthe chemokine/chemokine-receptor system. Cytokine Growth Factor Rev 2020;53:25-32
13. Muller I,Cannavaro D, Dazzi D, Covelli D,Mantovani G,Muscatello A. et al. SARS-CoV-2 related atypical thyroiditis. Lancet Diabetes Endocrinol 2020;8(9):739-741.

14. Zhang Y, Lin F, Tu W, Zhang J, Choudhry AA, Ahmed O.et al Thyroid dysfunction may be associated with poor outcomes in patients with COVID-19. medical team from Xiangye Hospital to support Hubei, China. Mol Cell Endocrinol 2021;521:111097.

15. Georges JL, Cochet H, Roger G,Jemaa HB, Soltani J, Azowa J-B et al. [Association of hy pertension and antihypertensive agents and the severity of COVID-19 pneumonia. A monocentric French prospective study]. Ann Cardiol Angeiol (Paris) 2020;69(5):247-254

16. Hariyanto TI, Kurniawan A. Thyroid disease is associated with severe coronavirus disease 2019 (COVID-19) infection.Diabetes Metab Syndr 2020;14(5):1429-1430.

17. Lagadinou M, Zareifopoulos N, Karela A, Kyriakopoulou O, Velissaris D. Are patients with autoimmune disease at greater risk of developing severe COVID-19? J Clin Med Res 2020;12(8):539-541.

18. Daraei M, Hasibi M, Abdollahi H, Hazaveh MM, Zebaradst J, Hajinoori M, et al Possible role of hypothyroidism in the prognosis of COVID-19. Intern Med J 2020;50(11):1410-1412.

19. Van Gerwen M, Alsen M, Little C,Barlow J, Genden E, Naymagon L,et al. Risk factors and outcomes of COVID-19 in New York City; a retrospective cohort study. J Med Virol 2021;93(2):907-915

20. Brix TH, Hegedüs L, Hallas J, Lund LC. Risk and course of SARS-CoV-2 infection in patients treated for hypothyroidism and hyperthyroidism.Lancet Diabetes Endocrinol 2021;9(4):197-199.

21. Güven $M$, Gültekin $H$. The prognostic impact of thyroid disorders on the clinical severity of COVID-19: Results of single-centre pandemic hospital. Int J Clin Pract 2021 ;75(6):e14129.

22. Lisco G, De Tullio A, Jirillo E, Giagulli VA, De Pergola G, Guastamacchia E et al. Thyroid and COVID-19: a review on pathophysiological, clinical and organizational aspects.J Endocrinol Invest 2021;25:1-14. 